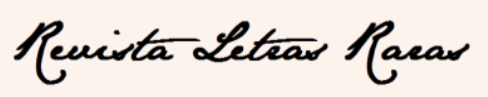

ISSN: $2317-2347$ - v. 8, n. 3 (2019)

\title{
Futuro do pretérito
}

Dayane Campos da Cunha Moura*

Recebido em 28 jun. 2019. Aprovado em 04 ago. 2019.

Eu poderia escrever um romance ou um livro de contos, poderia dormir ou ouvir de novo aquela música que tanto fere, porque traduz a ferida. Eu poderia deixar virem as lágrimas fruto-dessa-dor-que-dói-tanto e em silêncio e que às vezes dá até para fingir que passou. Poderia terminar a leitura daqueles cinco livros ali na estante ou começar outros dez, poderia retomar o trabalho, planejar o amanhã, apesar de tantos hojes inacabados, eu poderia copiar uma receita, ignorar o nome, simular o sorriso prova de que está tudo sempre indo muito bem graças a deus, obrigada, e você? Eu poderia voltar a perguntar ou de novo responder ao que nunca foi perguntado, poderia tentar decifrar a cor do que não tem nome, poderia assumir o fracasso ou reinventar pequenos sucessos cotidianos. Poderia perguntar ao pai por que há palavras que violentam sonhos, pedir à mãe que explique todas as faces do abandono, esse, que praticou tantas vezes. Poderia pedir ao avô mais uma história enquanto esperamos uma luz que não virá, perguntar à avó qual o segredo do gato que se esconde sob a cama. Poderia sentir aquele amor primeiro, imenso, profundo como só aos seis anos é possível conhecer. Poderia perguntar pelo sangue que desce de algum lugar entre os cabelos e se revela no rosto enquanto a irmã se esconde atrás da casa para perguntar depois se ela/eu vou morrer. Eu poderia esquecer o dia em que conheci as lágrimas do pai, o dia em que senti pena porque em vez de xingar, porque em vez de acusar, admitia um pouco o fracasso daquela vida que não correspondia em [quase] nada a uma vida sonhada anos atrás. Eu poderia recriar os caminhos, reviver as parcas alegrias e a humilhação de não saber aonde ir quando não podia permanecer. Poderia escutar de novo aquelas músicas que acordavam a casa, aquele momento em que o dia era ainda promessa. Sempre acreditei em promessas. Eu poderia retomar aquele conto iniciado há meses ou me preparar para novos começos sem ipês amarelos e alguém que tenta se lembrar das palavras ouvidas

\footnotetext{
* Doutoranda em Estudos Literários na Universidade Federal de Juiz de Fora (UFJF), Brasil, daymoura24@yahoo.com.br.
} 


\section{Peuista Letras Paras}

ISSN: $2317-2347$ - v. 8, n. 3 (2019)

na manhã do mesmo dia em que já não haverá ipês. Poderia mudar o título se alterando o nome das flores o final jamais escrito pudesse ser evitado. Poderia escolher epígrafes, escrever a introdução e os agradecimentos, ordenar referências, deixar tudo de lado. Eu poderia acreditar na humanidade do ser humano ou aceitar que \#somostodosmonstros debaixo da cama da criança que fomos um dia. Poderia, se poder fosse mais que um verbo, afastar essa criança que dorme -e sonha- dos pesadelos inevitáveis que um dia acordarão sua inocência. Eu poderia ser otimista, ler o milagre da manhã, como ser feliz em 24 passos, como fazer amigos e influenciar pessoas, como ser um funcionário exemplar, como comer, como rezar, como amar, como acordar, como fingir que a dor do outro não me diz respeito, sorria, você está sendo filmado. Poderia entrar em uma conversa como quem entra numa luta desarmada, pronto para opor flores às armas amigas, poderia só ouvir e ouvir ser o bastante. Poderia dar vinte-e-quatro passos em direção à felicidade. Poderia me perguntar, perguntar a quem dorme, a quem está acordado, qual é o passo que inaugura os outros vinte e três. Poderia estar só aqui. Estou só aqui. Só aqui, no presente. Só, aqui no presente. 